\title{
Does the COVID-19 pandemic reveal challenges for open science and the credibility of scientific dissemination?
}

\author{
A pandemia do COVID-19 revela desafios para a ciência aberta e credibilidade da \\ divulgação científica?
}

\author{
Maria Garbi NOVAES ${ }^{1}$, Dirce Bellezi GUILHEM ${ }^{2}$
}

Submitted: 30-04-2020 Accepted: 04-05-2020

The COVID-19 timeline takes us back to December 2019 and to the city of Wuhan, China, where the outbreak began. The intermediate source of origin and transfer to humans is not yet confirmed; however, its rapid transmission between them is widely known ${ }^{1}$. This scenario requires an endless search for information and knowledge that can subsidize health professionals and services in facing the disproportionate demand of people affected by the disease who seek these institutions. And, on the other hand, to provide society in general with tools for the new health prevention and promotion needs which emerge from this new reality ${ }^{2}$.

With the growing demand for new information about a new and rapidly spreading disease, there is great effort by research groups around the world to produce responses in the shortest possible time. This movement will possibly ensure that the pandemic is experienced with less loss of human lives and with the definition of the best ways to reduce the contagion and to perform effective and safe treatments for combating the infection.

However, "the coronavirus (COVID-19) outbreak exposes an inconvenient truth about science: the current system of scientific communication does not meet the needs of science and society. The crisis manifests two inefficiencies in the research system: the standard for closed science and the excessive emphasis on elite publishing, only in English, and regardless of the context and consequences of the research." ${ }^{3}$ In other words, this model brings with it often insurmountable barriers: the lack of mastery of the English language by potential users of the system, and exposure to economic limitations for the release of articles of interest, when it is observed that, of the 13,818 articles published on the subject of coronaviruses since the late 1960 s, more than half $(51.5 \%)$ remain closed for access according to the Web of Science (WoS) ${ }^{3}$.

In the context of the epidemic, scientific communication related to COVID-19 stimulated the opening of the system, encouraging the sharing of scientific articles in the form of preprints on virtual platforms, which would favor collaboration and discussion between scientists, health professionals and society, enabling public and immediate access to research results.

A preprint "is a version of a manuscript before peer review, who certify or not its formal publication in a journal."4 This model offers the advantage of quickly making the article available, giving visibility to previously invisible works and obtaining comments from other researchers who can contribute to the improvement of the work ${ }^{4}$. Researchers interpret research as another step in the study of a given theme and are able to discern that the results presented do not yet have the possibility of specific and safe application for the population, which does not make the study dispensable in the process of maturing for the development of products and evidence for later use ${ }^{6}$.

On the other hand, free access to the results and the use of scientific knowledge promoted for open science cause insecurity for the lay public due to their lack of knowledge to interpret and assimilate the available information. The practice of Preprints refers to an uncomfortable issue regarding the reliability and low scientific evidence of the published studies. Aiming to accelerate the dissemination of scientific knowledge, texts that have not been reviewed or revised, but with little robust methodological designs, are being published and serving as a reference for the public, and also for the continuation of new research studies ${ }^{5}$.

With all the limitations that may be mentioned, the peer review process remains as the gold standard for analyzing the results of the research studies to be released. It contributes to the selection of credibility and to the high quality of the publications, as well as it guarantees the correction of any errors or issues present in the articles submitted. It offers the reader the opportunity to come across meaningful research questions, robust methodological designs, and conclusions based on professionally executed experimentation ${ }^{7}$.

Open science and speedy peer reviews are needed during the COVID-19 pandemic. However, the ethical requirements for research involving human beings cannot be made lax in the name of science. The rigor of the ethical and scientific review remains mandatory, as well as the process for implementing and conducting the research, observing the process of obtaining free and informed consents, collection and processing of samples, and guarantees of treatment at the end of the studies. In addition, as this is a global health emergency, the results obtained must be immediately shared so that they support the decision-making process in public health ${ }^{8}$.

1 Maria Rita Carvalho Garbi Novaes is a pharmacist, Post-Doctorate in Research Ethics by the University of Chile, professor and advisor of the strictu sensu post-graduate course in Health Sciences at the University of Brasília (UnB) and at the Health Sciences Higher School (Escola Superior de Ciências da Saúde, ESCS/FEPECS), Consultant of the Conep/CNS, and associate editor of the Brazilian Journal of Hospital Pharmacy and Health Services.

2 Dirce Bellezi Guilhem is a nurse. PhD in Health Sciences (Bioethics) by the University of Brasilia (UnB), Post-Doctorate in Bioethics by the Universidad Complutense of Madrid, and Post-Doctorate in Public Health by the University College London (UCL), full professor at the UnB, advisor of the Post-Graduate Programs in Health Sciences, Nursing, and Collective Health at the UnB. 


\section{References}

1. Shereen MA, Khan S, Kazmi A, Bashir N, Siddique R. COVID-19 infection: origin, transmission, and characteristics of human coronaviruses. J Adv Res 2020;24:91-98.

2. Johns Hopkins University \& Medicine. Coronavirus Resource Center. COVID-19 Case Tracker. Avaliable from https:// coronavirus.jhu.edu/. Accessed on 30 de abril de 2020.

3. Larivière V, Shu F, Sugimoto C. O surto de coronavírus (COVID19) ressalta sérias deficiências na comunicação científica [Publicado originalmente no LSE Impact Blog em março/2020] [online]. SciELO em Perspectiva, 2020. Available from https:// blog.scielo.org/blog/2020/03/12/o-surto-de-coronaviruscovid-19-ressalta-serias-deficiencias-na-comunicacaocientifica/. Accessed on 30 de abril de 2020.

4. Spinak E. O que é este tema dos preprints? [online]. SciELO em Perspectiva, 2016. Available from https://blog.scielo. org/blog/2016/11/22/o-que-e-este-tema-dos-preprints/. Accessed on 30 de abril de 2020.

5. Chiarelli A, Johnson R, Pinfield S, Richens E. Preprints and scholarly communication: an exploratory qualitative study of adoption, practices, drivers and barriers [version 2; peer review: 3 approved, 1 approved with reservations]. F1000Research 2019;8(971): 1-74. Last updated: 04 FEB 2020. Accessed on 30 de abril de 2020.

6. Packer Al, Santos S. Ciencia abierta y el nuevo modus operandi de comunicar la investigación - Parte I [online]. SciELO en Perspectiva, 2019. Available from https://blog.scielo.org/ es/2019/08/01/ciencia-abierta-y-el-nuevo-modus-operandide-comunicar-la-investigacion-parte-i/. Accessed on 30 de abril de 2020.

7. Kelly J, Sadeghieh T, Adeli K. Peer review in scientific publications: benefits, critiques, \& a survival guide. EJIFCC. 2014;25(3):227-243. eJIFCC2014Vol25No3pp227-243. Available from http://www.ifcc.org/media/332102/ eJIFCC2014Vol25No3pp227-243.pdf. Accessed on 30 de abril de 2020.

8. Organización Panamericana de la Salud. Programa Regional de Bioética, Departamento de Sistemas y Servicios de Salud. Orientación ética sobre cuestiones planteadas por la pandemia del nuevo coronavirus (COVID-19). Washington DC: OPS; 2020. Available from https://www.paho.org/es/ documentos/orientacion-etica-sobre-cuestiones-planteadaspor-pandemia-nuevo-coronavirus-covid-19. Accessed on 30 de abril de 2020 . 